\title{
The Anniversary of a Massacre and the Death of a Monarch
}

\section{TYRELL HABERKORN}

\begin{abstract}
$\mathrm{A}$ S PART OF THIS year's anniversary of the October 6, 1976, massacre at Thammasat University, an outdoor exhibit of photographs of the violence and the three preceding years of student and other social movements was displayed upon the very soccer field in the center of campus where students were beaten, shot, lynched, and murdered forty years prior. Several of the photographs were printed on large sheets of acrylic and positioned such that the images of the buildings in the photographs were aligned with the actual buildings, which remain largely unchanged. The most striking of these was a photograph of hundreds of students stripped to the waist who were lying face down on the soccer field prior to being arrested and taken away. At the edge of the image was the top of the university's iconic dome building, which lined up with the existing building. The organizers explained that their intention was "to reflect a perspective on the past through the eyes of people in the present in order to show the cruelty of humans to one another."1 The proximity generated by the image was underlined by the fact that the fortieth anniversary of the massacre and coup in 1976 that led to twelve years of dictatorship was taking place under yet another dictatorship, that of a military junta calling itself the National Council for Peace and Order (NCPO), which seized power on May 22, 2014 , in the twelfth coup since the end of the absolute monarchy on June $24,1932 .^{2}$ Suchada Chakphisut, founding editor of Sarakadee magazine and Thai Civil Rights and Investigative Journalism, who was a first-year Thammasat student during the massacre, began her autobiographical account of the day, written for the anniversary this year, by writing: "We meet every year when 6 October comes around, and with it an inexplicable sadness always takes hold of my psyche. It has grown even more devastating since the 22 May 2014 coup, in which we must face the news of the arrest and detention of activists and those who oppose dictatorship."3 This was not a commemoration after
\end{abstract}

Tyrell Haberkorn (tyrell.haberkorn@anu.edu.au) is Fellow in the Department of Political and Social Change at Australian National University.

${ }^{1}$ All translations in this article are my own. When citing Thai-language sources, I first specify the Buddhist Era publication date and then include the Common Era date in brackets immediately following. Khana Kammakan Damnoen Kan Chad Ngan 40 Pi 6 Tula [40th Anniversary of 6 October Event Committee], 40 Pi 6 Tula raluk: Nithasakan roi luat lae khrab namtha [Remembering 40 years of 6 October: An exhibition upon dried blood and tears] (Bangkok: Khana Kammakan Damnoen Kan Chad Ngan 40 Pi 6 Tula [40th Anniversary of 6 October Event Committee], Mahawitthayalai Thammasat [Thammasat University], 2559 [2016]), 17.

${ }^{2}$ The number of coups is thirteen if one counts the June 24,1932 , transformation from absolute to constitutional monarchy as a coup. There have been at least seven attempted coups during this same period. 
dictatorship such as those of the same era held in Argentina or Chile during recent years of democratization, but memories of dictatorship in situ. ${ }^{4}$

Forty years earlier, the dehumanization of students who were dissident and dared to dream of a different Thai society made it possible for them to be brutally killed. Beginning in late September 1976, students peacefully organized in Bangkok and other cities after Thanom Kittikhachorn, one of the dictators ousted three years earlier, returned to the country. For students, his return signaled a possible coup and return to dictatorship; for the right-wing inside and outside the state, the student protests sparked alarm of a possible communist revolution following transitions in Vietnam, Laos, and Cambodia the prior year. On September 24, two worker activists who made a poster decrying Thanom's return were hanged and murdered in Nakhon Pathom, a province bordering Bangkok. At noon on October 4, students were massed inside Thammasat University in ongoing protests and a student theater group performed a play about the hanging of the two worker activists. By October 5 , right-wing newspapers and military radio reported on the play, but claimed that it was a mock hanging of Crown Prince Vajiralongkorn.

Before dawn on October 6, 1976, spurred on by these reports and allegations that the students were alien communists, right-wing state and para-state forces shot rockets and bullets into the campus and then entered the gates wielding guns, large pieces of wood, and other objects used as weapons. They treated the unarmed students as inhuman enemies who intended to destroy the three key institutions of the monarchy, the nation, and the Buddhist religion. Forty-one students and other dissident citizens are known to have been shot, beaten to death, or hanged, and their bodies were brutalized in other ways, including the mutilation and burning of corpses. That evening, the final end of the three years of open politics that began on October 14, 1973, arrived with a coup by a military junta calling itself the National Administrative Reform Council (NARC). ${ }^{5}$

${ }^{3}$ Suchada Chakphisut "Lum mai dai cham mai long" [Unforgettable, unrememberable], Sun Khomun \& Khao Subsuan Phua Sitthi Phonlamuang [Thai Civil Rights and Investigative Journalism], TCIJ, October 6, 2016, http://www.tcijthai.com/tcijthainews/view.php?ids=6448 (accessed November 2, 2016).

${ }^{4}$ See Macarena Gómez-Barris, Where Memory Dwells: Culture and State Violence in Chile (Berkeley: University of California Press, 2009); Susana Kaiser, Postmemories of Terror: A New Generation Copes with the Legacy of the "Dirty War" (New York: Palgrave Macmillan, 2005).

${ }^{5}$ After fifteen years under the dictatorial regimes of Field Marshal Sarit Thanarat (1958-63) and Field Marshal Thanom Kittikachorn, in early October 1973, Thai students and people began to call for a new constitution. Over a period of less than two weeks, the initial call by a small number of people grew into protests of several hundred thousand people in the streets in Bangkok and provinces around the country. The protests climaxed with clashes between the people and state forces on October 14, after which King Bhumipol intervened to ask Thanom and his two deputies to leave the country. During the next three years, elections were held; a democratic constitution was written; and a range of previously marginalized groups, including students, workers, farmers, and many others, organized and demanded their rights and the transformation of Thai society. By late 1974, a backlash to this open politics began in the form of state and para-state attacks on activists. For an overview of the period, see Charnvit Kasetsiri and Thamrongsak Petchlertanan, eds., Chak 14 thung 6 Tula [From 14 to 6 October] (Bangkok: Thammasat University Press, 2541 [1998]); David Morell and Chai-anan Samudavanija, Political Conflict in Thailand: Reform, Reaction, Revolution (Cambridge, Mass.: Oelgeschlager, Gunn and Hain, 1981). For an analysis of the farmers' movement, its revolutionary potential, and the backlash it engendered, 
An article in the constitution promulgated by the NARC as well as a stand-alone amnesty law passed in December 1976 gave a legal gloss to the coup and the massacre and placed the perpetrators beyond prosecution. Throughout the drafting and debate in the assembly appointed by the junta, as a reason to pass the amnesty, reference was made to the need to protect those who acted out of loyalty to the monarchy. The precise actions in need of protection were not named, but the claim to loyalty was enough to justify its passage. Those who were arrested at Thammasat University on October 6, 1976, were not the perpetrators of violence, but its victims and survivors. Eighteen of those arrested were detained, charged with grave crimes against the crown and state, and prosecuted in military court until a second amnesty was passed that led to their release after nearly two years in September 1978, yet also further cemented the impunity of the perpetrators. ${ }^{6}$ Forty years later, the perpetrators of the massacre remain unnamed and unpunished. The death of Rama IX, King Bhumipol Adulyadej, one week after the anniversary on October 13, 2016, and the subsequent naming of the former crown prince as Rama X, King Maha Vajiralongkorn, may make it even more difficult to name the perpetrators, as Rama IX's reign becomes further idealized and the lèse majesté regime broadens. ${ }^{7}$

\section{Recalling Past Violence under the Present Dictatorship}

Shaped by the ten years of color-coded red and yellow contention and street protests preceding the coup and first the impending death of the king, Bhumipol Adulyadej, and then his actual death, the NCPO has curtailed political freedom and freedom of expression using techniques borrowed from prior dictatorships as well as new innovations. This has included extensive use of the courts, including prosecution of civilians in military courts for crimes against the crown and state for the first time since $1976 .^{8}$ Article

see Tyrell Haberkorn, Revolution Interrupted: Farmers, Students, Law, and Violence in Northern Thailand (Madison: University of Wisconsin Press, 2011). For an analysis of one of the para-state groups active during this period, the Village Scouts, see Katherine Bowie, Rituals of National Loyalty: The State and the Village Scout Movement in Thailand (New York: Columbia University Press, 1997). For a timeline of events on October 6, 1976, itself, see Puey Ungpakorn, "Violence and the Military Coup in Thailand," Bulletin of Concerned Asian Scholars 9, no. 3 (1977): 4-12. Puey notes that the NARC said that 41 were killed, several hundred injured, and 3,037 arrested, but that "sources at the Chinese Benevolent Foundation, which transported and cremated the dead, it was revealed [sic] that they handled 'over a hundred corpses' that day" (8).

${ }^{6}$ The importance of loyalty to the monarchy was stressed in the debates about both of the amnesty laws. See Tyrell Haberkorn, "A Hidden Transcript of Amnesty: The 6 October 1976 Massacre and Coup in Thailand," Critical Asian Studies 47, no. 1 (2015): 44-68.

${ }^{7}$ This idealization is a key part of the phenomenon of what Thongchai Winichakul identifies as hyper-royalism. See Thongchai Winichakul, Thailand's Hyper-royalism: Its Past Success and Present Predicament, ISEAS Trends in Southeast Asia no. 7 (Singapore: ISEAS, 2016).

${ }^{8}$ Between May 22, 2014, and May 31, 2016, a total of 1,546 cases involving 1,811 civilians were initiated in the Bangkok and provincial military courts. The vast majority of these cases $(1,331)$ are related to weapons charges, many of which are possession charges. New cases involving civilians ceased to be placed within the jurisdiction of the military court system effective as of September 12, 2016, according to Head of the NCPO Order no. 55/2559. Adjudication of cases already 
112, which defines and stipulates the punishment for lèse majesté, has been widely used against critics of the monarchy and ordinary citizens, with at least ninety new known cases since the coup. Article 116, which defines and stipulates the punishment for alleged sedition, has been taken up against dissidents who oppose the NCPO, with at least fifty-eight new known cases since the coup. In addition to the use of existing laws, the NCPO has also issued executive orders to expand its powers of control. One of these is NCPO Order no. 7/2557, later replaced by Head of the NCPO Order no. 3/2558, which criminalizes any public gathering of five or more persons and has been used to shut down any protests, with at least 254 people charged since the coup. ${ }^{9}$ Any public discussion or event, including university seminars, requires prior permission from the authorities, and those who do not secure it may face the electricity to the building being cut, the seminar being interrupted by soldiers in fatigues, or the speakers being arrested during or after the event. During the first two years of NCPO rule, at least 130 seminars were forbidden or interrupted and shut down. ${ }^{10}$ Those events permitted are then often heavily surveilled by military and police intelligence.

Although the NCPO allowed nearly all of the events surrounding the fortieth anniversary of the October 6,1976 , massacre to take place, it repeatedly warned that extra intelligence would be deployed and any untoward events would be shut down. ${ }^{11}$ The clumsy officials were visible during the events, clad in polo shirts advertising Glock and other gun brands and methodically photographing the speakers and participants. Despite their presence, survivors, cultural activists, scholars, and university students named what is known and not known about the massacre, queried whose voices remain unheard in the limited circulation of information about the massacre, explored the meanings of the massacre for a new generation, discussed the roles of the media in criticizing the state, and linked impunity for the massacre with other instances of impunity for state and para-state violence in Thailand. The series of seminars, films, and

initiated in the military court system will be completed within it. See Thai Lawyers for Human Rights, "Updated Statistics of Civilians Being Tried in Military Courts Since the 2014 Coup," August 24, 2016, http://www.tlhr2014.com/th/?p=1777 (accessed October 30, 2016); International Commission of Jurists, "Thailand: ICJ Welcomes Order Phasing Out Prosecution of Civilians in Military Courts but Government Must Do Much More," September 12, 2016, http://www.icj. org/thailand-icj-welcomes-order-phasing-out-prosecution-of-civilians-in-military-courts-but-government-must-do-much-more/ (accessed October 30, 2016).

${ }^{9}$ This number was current as of March 2017. The case statistics are drawn from those updated monthly by iLaw: see http://freedom.ilaw.or.th. The punishment for violation of Article 112 is three to fifteen years' imprisonment per count; for Article 116, it is up to seven years' imprisonment per count; for NCPO Order no. 7/2557, it is up to one year of imprisonment per count and/or a fine of up to 20,000 baht (570 USD); and for violation of Head of the NCPO Order no. $3 / 2558$, it is up to six months' imprisonment and/or a fine of up to 10,000 baht (285 USD).

${ }^{10}$ Thai Lawyers for Human Rights, "The Force of the Gun Camouflaged as Law and a Justice System," August 2, 2016, http://www.tlhr2014.com/th/?p=1443 (accessed November 3, 2016).

${ }^{11}$ On the thirty-eighth anniversary of the massacre in 2014, the NCPO forbade students at the Lampang campus of Thammasat University from holding a commemorative event. Prachatai, "Thahan ham naksuksa mo to sun Lampang chad ngan ramluk 6 Tula" [Soldiers forbid students at TU Lampang from holding a 6 October commemoration], October 3, 2014, http://prachatai. com/journal/2014/10/55828 (accessed November 4, 2016). 
publications leading up to and during the anniversary transformed the place of the massacre in recent Thai history and also operated as a profound critique of ongoing military rule. As Suchada noted, resurgent dictatorship makes the memory of past violence more devastating, but it also makes the search for justice and shared humanity even more urgent in the present.

The fortieth-anniversary events were concentrated during October 6-8, 2016, at Thammasat University and included lectures, films, musical performances, and other cultural and political activities. ${ }^{12}$ Survivors and relatives of those killed gather yearly on the 6th at dawn on the campus to hold a ceremony to make merit for and honor those killed, but this year's anniversary was both the largest since the twentieth anniversary in 1996 and the largest number of people gathered in public to critique an instance of state violence past or present since the 2014 coup. In addition to the photo exhibit on the soccer field, over twenty publishing houses sold progressive books outside the auditorium where lectures and films were held; hundreds of people circulated in these areas as well as in the sculpture garden adjacent to the auditorium that contains a small memorial to the massacre. Survivors of the massacre, activists and intellectuals of later generations, journalists, university students, and human rights lawyers defending those accused of lèse majesté and sedition in the present all rubbed shoulders and chatted in the hours between the morning ceremony and the program of films and lectures in the afternoon and evening.

By late afternoon, many filed into the auditorium to listen to a panel of survivors of other instances of state violence in Thailand - the October 14, 1973, uprising; the May 1992 movement; the crackdown on red shirt protestors in 2010; and ongoing violence in southern Thailand since 2004-discuss the significant obstacles in holding state officials to account for extrajudicial violence. The perpetrators of the October 6, 1976, massacre are not the only ones who have not been held to account: except in a few exceptional and individual cases, perpetrators have not been prosecuted. ${ }^{13}$ Then, with the premiere of a new film about the October 6, 1976, massacre and the keynote address of the evening, the demand for justice took the form of a call for radical humanity. The lives of those killed on the 6th and their families and friends are at the center of the short documentary, Duai khwamnapthue (Respectfully yours), produced by Patporn Phoothong and Puangthong Pawakapan. Building on Patporn's first film, Khwamsongcham rai siang (Silence-memories), which uses interviews with the parents of two students killed on October 6 to break open what remains unknown about the event, Respectfully yours narrates the stories of an additional eleven people who were killed. Rather than collect accounts of the violence, Puangthong noted that their purpose was "to let people learn about their identities that existed prior to the brutal suspension of

\footnotetext{
${ }^{12}$ See 40 th Anniversary of 6 October Event Committee, op. cit. note 1, 6-9, for a listing of the events held at Thammasat.

${ }^{13}$ Across the three days of the anniversary events, the massacre was placed in an explicitly broad and comparative frame. This took the form of screenings of films about state violence and memory in Cambodia, Indonesia, Burma, and Germany across the three days as well as the premiere of Prachathipatai lang khwamtai [Democracy after death], a film about the suicide of Uncle Nuamthong Praiwan, who killed himself rather than live under military rule after the September 19, 2006, coup; and a mini-conference of six papers about impunity in Thailand on October 8, 2016. The papers were published as a special journal edition: Fa Diew Kan 14, no. 2 (May-December 2559 [2016]).
} 
their lives. We are doing this because we realized that after 40 years, we still know very little about their individual lives." 14 She also commented that, "It feels odd - we commemorate their deaths, but we do not know them."15 During the introduction to the film, Puangthong explained that they began to search for the families using the addresses listed on the death certificates completed by physicians at government hospitals in the days following the massacre. Some families said that they had been waiting for forty years for someone to come and ask them about what happened, while others remained fearful of the possible consequences of speaking about the past. This fear was deepened within the context of the NCPO's regime. Puangthong said that " $[t]$ here was one family in which the older sister of the person killed granted an interview without any difficulty. Several days later, she called and said that her husband and daughter asked for neither her face nor her real name to be shown because they were worried since we are now under a military government." ${ }^{16}$ Rather than the use of images of the vicious methods by which the victims of the massacre were killed, which are not present in the film, the power of the film comes from the precision with which their relatives and friends remembered them. The film marks the beginning of a new digital archive project to collect information about the lives of those who were killed on October 6, $1976 .{ }^{17}$

The call for radical humanity continued with the address of Thongchai Winichakul, historian and one of the eighteen student activists imprisoned for nearly two years following the massacre. During the months prior to the anniversary, survivors, scholars, and activists argued about what remains unknown about the massacre, in particular the precise number of people who were hanged and their identities. ${ }^{18}$ On the evening of the fortieth anniversary, Thongchai explained that even basic information about many of those who were killed, including their names, remains unknown. He argued that searching for this information will not change the basic understanding of what happened, but will instead transform the very texture of what is known. He said:

[T]he importance of the details is that they could be harmed and victimized to that degree because they were made to be less than human. The importance of the details is that it makes them human.... One important way of returning their

\footnotetext{
${ }^{14}$ Prachatai English, "Culture of Impunity and the Thai Ruling Class: Interview with Puangthong Pawakapan," October 3, 2016, http://www.prachatai.com/english/node/6612 (accessed November 2, 2016).

${ }^{15}$ Matichon “'Khon tai mi chu': Tam ha khomun thi hai pai na '6 Tula 19' Puangthong PawakapanPatporn Phoothong" ["The dead have names": Looking for missing information about "6 October 1976" Puangthong Pawakapan-Patporn Phoothong], October 8, 2016, http://www.matichon.co.th/ news/313485 (accessed November 3, 2016).

${ }^{16} \mathrm{Ibid}$.

${ }^{17}$ For more information, see 6 October Photo, http://www.6oct-photo.com.

${ }^{18}$ Until this year, observers thought that two people were hanged during the massacre, including the young man at the center of Neal Ulevich's Pulitzer Prize-winning photograph of a man using a chair to beat a corpse hanging from a tree while a crowd of smiling onlookers cheered. Examining news photographs and footage, there is a new consensus that there were at least four different hangings, and perhaps up to six. Matichon, "Sarup sewana 'khwam ru lae khwam mai ru wa duay '6 Tula 2519': 40 pi thi yang ha khamtop mai dai" [Summary of seminar on "knowns and unknowns" about "6 October 2519": 40 years without finding answers], September 30, 2016, http://www.matichon.co. th/news/304265 (accessed November 1, 2016).
} 
humanity is to search for justice and struggle for an end to impunity. But this is an arduous struggle. We know this well. It may take more than our lifetimes. What is important is that this struggle should be paired with calling for society to recognize, respect and not destroy humanity any more. The best way to do so is to return the humanity to each of those who was attacked on that day. How can we do this? Those of us in the present, how do we want other people to respect us? This is the way that we return humanity to those who died. We have names. We have families. We have parents and brothers and sisters. We have faces. We want others to respect us as individuals who are not the same as anyone else. So we should return the names, the faces, the families, and the stories of those that we are able to find. We should return their individuality to them. ${ }^{19}$

Thongchai then read the names of those who were killed, accompanied with slides of photographs in the few cases in which they exist. The names of thirty men and four women who were killed are known, but three men who were killed remain unnamed and the identities of four bodies that were burned remain unknown. Quiet descended upon the overflowing auditorium for the nearly eight minutes during which he read the names.

Different than the demand to open state archives about the massacre, which remain largely closed, the restoration of the humanity of those killed instead calls on those who remain to reassess what is known and unknown. Talking about both the making of Respectfully yours and her research to determine how many people were hanged, Patporn noted that the information was readily found in old newspapers, in video clips, and on YouTube. The question this prompted, she said, is why has no one looked at this information before ${ }^{20}$ Similar to recent reexaminations of anti-communist violence in Indonesia during 1965-66, new approaches to existing information, in addition to new information, are transforming what is known about the victims and perpetrators of the October 6, 1976, massacre. ${ }^{21}$ This strategy was also taken up by students at Chulalongkorn University across the city from Thammasat.

While Thammasat was founded as an open university in 1934 by Pridi Banomyong, one of the leaders of the People's Party who fomented the transformation from absolute to constitutional monarchy, and has a reputation as a center of progressive thought and activism, Chulalongkorn was initially founded in 1902 as the School for Royal Pages inside the palace and retains a reputation for conservatism. Netiwit Chotiphatphaisal, a first-year politics student who was a driving force behind an anniversary event and book at Chulalongkorn, explained that he assumed that the university's elitism meant that its history was not bound up with the massacre, but this changed when he talked to his seniors and professors. Ten students from Chulalongkorn were among those

\footnotetext{
${ }^{19}$ Thongchai Winichakul, "Khon yang yuen den doy thathai" [People keep standing in defiance], Prachatai, October 6, 2016, http://prachatai.com/journal/2016/10/68230 (accessed November 1, 2016).

${ }^{20}$ Matichon, “The dead have names," op. cit. note 15.

${ }^{21}$ John Roosa, "The State of Knowledge about an Open Secret: Indonesia's Mass Disappearances of 1965-66," Journal of Asian Studies 75, no. 2 (2016): 281-97.
} 
killed at Thammasat, and socialist books were taken from campus libraries and burned after the massacre. ${ }^{22}$ In response to what he did not know, he edited a book, Chula and 6 October: Selected Essays on the Fortieth Anniversary of 6 October 1976, with essays about the massacre by both former Chulalongkorn student survivors and current faculty. His hope is that the book will catalyze others to research the history of Chulalongkorn, the massacre, and struggles for democracy. ${ }^{23}$ Paired with the book, Netiwit and other students organized an event, "6 Tula: Chao Chula mong anakhot" (6 October: Chula looks towards the future), which extended commemoration in a new direction and was the only one in which the NCPO intervened directly. Instead of inviting those who lived through the period of the massacre to speak, the organizers invited seven young activists, writers, and media figures, including Hong Kong Umbrella Movement activist Joshua Wong, who was denied entry into the country on the evening of October 5 on the basis that he was a threat to national security. ${ }^{24}$ The combined efforts of the NCPO and the Chinese government were unable to stop Wong from joining the event via Skype after his return to Hong Kong and only served to bring additional attention to the event, which had over three times as many people interested in attending as those who could fit inside the auditorium. The panelists discussed their perspectives on the massacre as well as the role of the media in both the creation of hatred and the fostering of humanity in present-day Thai society. ${ }^{25}$

Other commemorative events surrounding the fortieth anniversary of the massacre were organized by students at other universities around the country. Students at Chiang Mai University in northern Thailand held an event entitled " 40 years of 6 October: Thopthuan ha chitwinyan khru phua muanchon” (40 years of 6 October: Looking back on the spirit of teachers for the masses), with talks by scholars and former teacher activists. Students at Mae Jo University, also in Chiang Mai Province, organized an evening of music and discussion about the massacre. Students at Kasetsart University in Bangkok held a seminar, "6 October: Thue khian khao lop rao mai luem tae rao chodcham: Bok lao 6 October phan khwamsongcham khong chao Kasetsart” (6 October: You write, they erase, but we remember: Memories of 6 October by people of Kasetsart). Students at the Lampang branch of Thammasat University organized a visual exhibit about the massacre. They requested and were granted permission by the university administration to hang the exhibit in the Faculty of Law, but then once they did so, some of the materials were removed by security guards. Upon protest by the students, the administration responded that some of the language in the exhibit was "inappropriate"; the students rehung their exhibit outside university buildings instead. ${ }^{26}$ Similar to recent initiatives

\footnotetext{
${ }^{22}$ Netiwit Chotiphatphaisal, "Khamnam” [Introduction], in Chula kap 6 Tula: Botkhwam khadsan nai wara khroprop sisip pi hetkan 6 tulakom pho. so. 2519 [Chula and 6 October: Selected essays on the fortieth anniversary of 6 October], ed. Netiwit Chotiphatphaisal (Bangkok: Demosisto, 2559 [2016]), 5-6.

${ }^{23}$ Ibid., $6-7$.

${ }^{24}$ Alan Wong and Edward Wong, "Joshua Wong, Hong Kong Democracy Leader, Is Detained at Bangkok Airport," New York Times, October 4, 2016, http://www.nytimes.com/2016/10/05/world/ asia/joshua-wong-thailand-hong-kong.html (accessed November 4, 2016).

${ }^{25}$ Pirawat Nawicharoen and Phatrasek Jirabovonvisut, "40 pi 6 Tula: Mua pakka khian bon kaewi” [40 years of 6 October: When the pen is upon the chair], CHU!, November 8, 2016, http://chu.in.th/ p/616 (accessed November 4, 2016).
} 
in Indonesia in which both children of survivors and those with no direct connection to the 1965-66 killings of communists have become involved in writing and organizing around past violence, these events organized by students around the country positioned the massacre as important for all in Thai society, not only those with a direct connection. ${ }^{27}$

There is no uniform calendar or trajectory determining when commemoration of past state violence becomes permissible, when citizens become curious or compelled to question past moments or periods of state violence, or when a regime is willing to hear and respond to concrete demands for truth, justice, and accountability. Instead, remembering past violence under authoritarian, recently authoritarian, hybrid, and democratic regimes is variously inflected with unease, uncertainty, and incompletion across Asia. In Indonesia, survivors and human rights activists began to initiate public discussion, investigations, and calls for accounting in relation to the 1965-66 killings of suspected communists and other instances of state violence during the two decades after the fall of General Suharto in 1998 and the slow turn toward democratization. ${ }^{28}$ While grassroots organizations around the country have emerged to address the violent past, attempts to do so nationally have faced greater obstacles. ${ }^{29}$ Significant prohibitions on speech remain, particularly with respect to investigating the roles of the military in the killings, who retain power and influence even within a more democratic Indonesia. Over twenty-seven years after the Tiananmen massacre of June 4, 1989, in China, public commemoration is forbidden and key details about the event, including the precise number killed and their identities, remain unclear. ${ }^{30}$ Circulation of information is strictly restricted by the government, and between 2011 and 2016, at least 262 words referring to the incident were banned from being searched online. ${ }^{31}$ The prohibition surrounding the massacre is so great that it has already rendered sites of violence elsewhere in China on the same date almost invisible, as Louisa Lim uncovers in the city of Chengdu. ${ }^{32}$ In South Korea, mobilizing around

${ }^{26}$ Matichon, "Kuab mai dai chad! Mo to Lampang ramluk 40 pi 6 Tula 19 tai tuk nithisat phuborihan sang kep tong ma chad khang nok taen" [Nearly unable to hold [the exhibit]! TU Lampang remembers 40 years of 6 October under the faculty of law, administration orders it taken down, must hold it outside instead], October 6, 2016, http://www.matichon.co.th/news/311299 (accessed January 3, 2017).

${ }^{27}$ For an overview, see Kartika Pratiwi, "Indonesia’s 1965 Tragedy: Hope Returns After 51 Years," EngageMedia, September 30, 2016 (accessed November 4, 2016). There are a number of different documentary and digital storytelling initiatives, including Ingat65 (https://medium.com/ingat-65), 1965setiaphari (http://1965setiaphari.org/), Learning1965 (http://www.learning65.com/), and Kotahitam Forum (http://www.kotahitamforum.org); Ken Setiawan, personal communication with the author, October 30, 2016.

${ }^{28}$ Douglas Kammen and Katherine McGregor, eds., The Contours of Mass Violence in Indonesia, 1965-1968 (Honolulu: University of Hawai'i Press, 2012).

${ }^{29}$ Annie E. Pohlman, "A Year of Truth and the Possibilities for Reconciliation in Indonesia," Genocide Studies and Prevention: An International Journal 10, no. 1 (2016): 60-78.

${ }^{30}$ Jeffrey N. Wasserstrom and Kate Merkel-Hess, "Popular Views of State Violence in China: The Tiananmen Incident," in State Violence in East Asia, eds. Narayanan Ganesan and Sung Chull Kim (Lexington: University Press of Kentucky, 2013), 105-28.

${ }^{31}$ Anne Henochowicz, "Five Years of Sensitive Words on June Fourth," China Digital Times, June 1, 2016, http://chinadigitaltimes.net/2016/06/five-years-sensitive-words-june-fourth/ (accessed November 11, 2016).

${ }^{32}$ Louisa Lim, The People's Republic of Amnesia: Tiananmen Revisited (Oxford: Oxford University Press, 2014). Lim's explanation of the precautions she took writing the book while living in China 
remembering and redressing the May 1980 Kwangju massacre was both a contributing factor and a result of the end of dictatorship in June 1987. Beginning in 1984, students and activists began commemorating the event with political and cultural activities at the cemetery where those killed were buried, and this action "became a battle between the state and the citizens, with the state trying to prevent visits by various means - making visits illegal, rendering access to the burial site difficult by leaving the road unpaved, and dispersing gatherings by force."33 Between 1987 and 1997, laws were passed providing compensation to families of those killed, recognition of the role of the people's uprising that preceded the massacre in opposing dictatorship, and ultimately prosecution of key and supporting figures responsible for the violence. Even though this seems remarkable in comparison to what has been possible to date in China and Indonesia, Namhee Lee assesses the shortcomings and notes that "the trial failed to establish a record or authoritative facts regarding the Kwangju massacre; defendants were evasive or disingenuous about their roles.... [N]o consensus was possible on the scale of casualties." 34 Unlike the Tiananmen massacre, commemoration of the October 6, 1976, massacre was not banned by the NCPO, but the naming, let alone prosecution, of perpetrators remains impossible.

\section{What REMAins UnSPEAKABLE}

After the twentieth anniversary of the massacre, Thongchai Winichakul wrote about the pervasive silence surrounding it in Thai society. He commented that during the anniversary, the role of the monarchy could not be raised and “...every organizer and participant fully realized that in order to preserve one's neck, one had to be aware of this limitation, and the likely consequences of violating it." ${ }^{35}$ While the institution of the monarchy benefited from the October 14, 1973, uprising because the king asked the three dictators to leave the country, the precise role of the monarchy in the October 6, 1976, massacre and coup remains murky. A profession of loyalty to the monarchy was enough to protect state officials and civilians who carried out actions that, while unspecified, were of a nature that the perpetrators felt they needed the protection of an amnesty law. But were members of the royal family or the institution itself directly involved, and if

underscore the sensitive and dangerous nature of researching the violence: "After signing a book deal, I made my editor promise not to contact me again until I got in touch with him. I warned my husband never to talk about the book at home. Then, to do the actual writing, I bought a computer that had never had online access and kept it locked in a safe in my bedroom." Louisa Lim, "I Wanted to Discover How Chinese People Became Complicit in an Act of Mass Amnesia," Guardian, July 21, 2015, https:/www.theguardian.com/books/booksblog/2015/jul/21/louisa-limthe-peoples-republic-of-amnesia-tiananmen-revisited-china (accessed November 11, 2016).

${ }^{33}$ Namhee Lee, "From the Streets to the National Assembly: Democratic Transition and Demands for Truth about Kwangju in South Korea," in State Violence in East Asia, eds. Narayanan Ganesan and Sung Chull Kim (Lexington: University Press of Kentucky, 2013), 54-55.

${ }^{34}$ Ibid., 66.

${ }^{35}$ Thongchai Winichakul, "Remembering/Silencing the Traumatic Past: The Ambivalent Memories of the October 1976 Massacre in Bangkok," in Cultural Crisis and Social Memory: Modernity and Identity in Thailand and Laos, eds. Shigeharu Tanabe and Charles Keyes (Honolulu: University of Hawai'i Press, 2002), 247. 
so, in what way(s)? During the intervening twenty years, particularly the last ten marked by the 2006 and 2014 coups, the prohibition on posing, let alone answering, this question has grown even greater. The presence of Somyot Prueksakasemsuk-human rights defender, labor activist, and editor-in prison is evidence of this prohibition. Somyot is serving a seven-year sentence for the act of publishing, not writing, two magazine articles querying the role of the monarchy in the massacre. ${ }^{36}$ During his address on the evening of the fortieth anniversary, Thongchai updated his assessment of the place of the massacre in public life in Thailand:

It is widely-known that the violence was brutal and should not happen again. This knowledge alone is of use and value to Thai society. But it is unfortunate that society is unable to say more than this.... We still do not dare to say who did it and why they did it, because every institution, without exception, was involved with this cruel incident. For this reason, 6 October perhaps still remains a "sensitive" matter. I think that after the twenty years, 6 October has ceased to be silent, but speaking about it remains limited. This state can be called "unforgettable, unrememberable." Awkward, half-silent/half-spoken. "Brutal, don't let it happen again" more than being a matter about which it is forbidden to speak. ${ }^{37}$

It is not only the October 6, 1976, massacre that remains "unforgettable, unrememberable." On the evening of the fortieth anniversary, Sarayut Tangprasert, an activist intellectual of the May 1992 generation, wrote about hearing stories of the violence during the long years of Cold War counterinsurgency between the late 1960s and mid-1980s from villagers in Mukdahan Province near the Phuphan mountain range in northeastern Thailand, including beheadings of suspected communists and assassinations of others by throwing them out of helicopters. ${ }^{38}$ The monarchy's support for and association with counterinsurgency means that investigating these additional instances of violence is also fraught.

Although the precise nature of the reign by Rama $\mathrm{X}$-the false accusation of whose mock hanging (as the crown prince) was used to instigate the October 6, 1976, massacre-will take some time to become clear, the death of Rama IX further constricted

\footnotetext{
${ }^{36}$ On April 30, 2011, Somyot was arrested and later charged with violating Article 112 in relation to two articles that were published in Voice of Taksin magazine, a print publication that he worked with as a key member of the editorial team. The two articles, published under the pseudonym Jit Phonlachan, were written by Jakrapop Penkair. On January 23, 2013, the Criminal Court judged Somyot guilty of two counts of violation of Article 112 and noted that even though he was not the author of the two articles in question, his work in editing, printing, distributing, and disseminating the articles was a violation equal to writing them. He was sentenced to eleven years in prison. This decision and sentence was upheld by the Appeal Court on September 19, 2014. On February 23, 2017, the Supreme Court upheld the conviction but reduced the sentence to seven years.

${ }^{37}$ Thongchai Winichakul, "People keep standing in defiance," op. cit. note 19.

${ }^{38}$ Sarayut Tangprasert, "Ya hai hetkan 6 Tula pen phiang prawatisat khwamrusuk" [Don't let 6 October be simply an emotional history], Blogazine, October 6, 2016, https://blogazine.pub/ blogs/gadfly/post/5863 (accessed November 4, 2016).
} 
the already-limited space for political expression and catalyzed an initial wave of royalist vigilantism. His death inaugurated an extended mourning period in which civil servants must wear black or white for a year and celebrations are to be muted. ${ }^{39}$ In the immediate aftermath, many seminars and conferences were also discouraged by the authorities as inappropriate. As part of this, Chiang Mai University canceled all student activities, including a follow-up event on October 6 planned for late October.

During the first two weeks following Rama IX's death, the police reported that twenty new Article 112 complaints were filed. ${ }^{40}$ Any individual can walk into a police station and file an Article 112 complaint, and the police are then compelled to investigate. This creates the potential for abuse of the law for personal disputes as well as by royalist vigilantes. ${ }^{41}$ Many of these concerned what royalist vigilantes perceived to be instances of insufficient mourning and were preceded by physical assaults of the alleged offender, such as in the case of a factory worker from Chonburi who was beaten very badly by a mob who then delivered him to the police. ${ }^{42}$ Although the vigilante attacks died out quickly, the NCPO's criticism of them was muted at best and matched by increased state resources devoted to surveillance of social media for anti-monarchy sentiment. ${ }^{43}$

Suchada Chakphisut, with whose observation on remembering the massacre under resurgent dictatorship I began, was one of the student theatre activists involved in the play about the hanging of the two workers. In her account, she wrote that she went home late on the afternoon of October 5, 1976, and turned on the radio to listen to music as she soothed her six-month-old niece to sleep. Instead of music, military radio was being broadcast live and it was announced that "Thammasat students performed a play hanging the Crown Prince. They are communists who harbor evil intentions to destroy the nation and topple the institution of the monarchy. I suddenly leapt up. I spoke back [to the radio] in my heart, "Not true. You are lying. It is you who harbor evil intentions to destroy the nation." 44

After forty years and with the country again under dictatorship, this retort to the dominant story maintained by the state still remains a quiet one. Unlike Beijing, which must actively ban Internet search terms that conjure the Tiananmen massacre, the return to military dictatorship after forty intervening years in which Thailand seemed to be on the path to democratization itself functions to limit demands to hold perpetrators

\footnotetext{
${ }^{39}$ Although not bound by the same restrictions on dress, by January 2017 most Thais (and many non-Thai residents and visitors) were still opting to wear muted colors.

${ }^{40}$ Prachatai, "Lèse Majesté Cases Spike to 20 Since King’s Death," October 28, 2016, http://www. prachatai.com/english/node/6679 (accessed November 4, 2016).

${ }^{41}$ An example of the abuse of the law in a personal dispute was the case of Yutthapoom, whose older brother brought an Article 112 case against him following arguments over a shared business and family pets. The Criminal Court dismissed the charges against Yutthapoom on September 13, 2013, but only after he had spent 359 days in pretrial and trial detention. For further details see iLaw, "Yutthapoom: 112 - Brother vs Brother," n.d., https://freedom.ilaw.or.th/en/case/439 (accessed November 4, 2016).

${ }^{42}$ Teeranai Charuvastra, "Chonburi Man Beaten by Mob Over Royal Defamation," Khao Sod, October 18, 2016, http://www.khaosodenglish.com/news/crimecourtscalamity/2016/10/18/ chonburi-man-beaten-mob-royal-defamation/ (accessed November 4, 2016).

${ }^{43}$ Prachatai, "Thailand to Monitor Social Media 24/7 in Mourning of King's Death," October 15, 2016, http://prachatai.com/english/node/6655 (accessed November 4, 2016).

${ }^{44}$ Suchada, "Unforgettable, unrememberable," op. cit. note 3.
} 
to account. Further, the struggle for justice of the victims of the October 6, 1976, massacre may become even more difficult within the context of the increased valorization of the reign of Rama IX, and the corresponding difficulty of questioning the military, judiciary, and other institutions closely linked to the monarchy, which is likely to come in the next few months and years. Under these conditions, restoring the humanity of those who were brutally killed becomes even more urgent. 